\title{
Teaching Reformation of Medicinal Chemistry Course of Pharmacy Major and Pharmaceutical Engineering Major
}

\author{
Wufu ZHU \\ School of Pharmacy \\ Jiangxi Science \& Technology Normal University \\ Nanchang 330013, China \\ zhuwufu-1122@163.com \\ Shan $\mathrm{XU}^{*}$ \\ School of Pharmacy \\ Jiangxi Science \& Technology Normal University \\ Nanchang 330013, China \\ *shanxu9891@126.com \\ Qidong TANG \\ School of Pharmacy \\ Jiangxi Science \& Technology Normal University \\ Nanchang 330013, China
}

\author{
Wenhui WANG \\ School of Pharmacy \\ Jiangxi Science \& Technology Normal University \\ Nanchang 330013, China
}

Yuping GUO

School of Pharmacy

Jiangxi Science \& Technology Normal University

Nanchang 330013, China

Pengwu ZHENG*

School of Pharmacy

Jiangxi Science \& Technology Normal University

Nanchang 330013, China

*zhengpw@126.com

\begin{abstract}
Medicinal chemistry is an important specialized course of students majoring in pharmacy and pharmaceutical engineering. In order to improve the teaching effect of Medicinal Chemistry, this article discusses the teaching methods of medicinal chemistry and told how to put the teaching reform into practice. Two methods including traditional way and new method were applied in the different classes. After two years' practice, the students from two classes exhibit different ability in understanding knowledge of medicinal chemistry. The results showed that the new method much better and the students can improve the learning ability in medicinal chemistry course for the students majoring in pharmacy and pharmaceutical engineering.
\end{abstract}

Keywords-Medicinal chemistry; Teaching reformation; Teaching experience; Pharmacy major; Pharmaceutical engineering major

\section{INTRODUCTION}

Medicinal chemistry is discipline at the intersection of chemistry, especially synthetic organic chemistry, and pharmacology and various other biological specialties, where they are involved with design, chemical synthesis and development for market of pharmaceutical agents, or bio-active molecules. Medicinal chemistry is a stimulating field as it links many scientific disciplines and allows for collaboration with other scientists in researching and developing new drugs [1-5].
Medicinal chemistry is an important specialized course for the students majoring in pharmacy and pharmaceutical engineering. Through learning medicinal chemistry, the pharmacy theories and the skills of practice of the undergraduate students can better understand and improved. Therefore, medicinal chemistry is a very important course for the students of the Pharmacy, and Pharmaceutical engineering and other related majors [6-9].

Most universities in China set medicinal chemistry course of the Pharmacy, and Pharmaceutical engineering and other related majors. In most of the universities, the teachers teach medicinal chemistry in traditional way, that is "ppt+teachers write on the blackboard+teacher teaching", even some

"985" and "211" Pharmaceutical universities, such as the China Pharmaceutical University and Shenyang Pharmaceutical University. There are few discussions on class and practice in Lab and pharmaceutical factory in medicinal chemistry. We know that pharmaceutical science is one important applied-science and practice in Lab and pharmaceutical factory is needed for these students. Little teaching reformation was carried out in these universities. Students have little interesting in medicinal chemistry class. Certainly, the students learn medicinal chemistry not very well [3-18]. 
TABLE I. Differences of Methods on Teaching Medicinal CHEMISTRY COURSE

\begin{tabular}{ccc}
\hline Items & $\begin{array}{c}\text { Most } \\
\text { universities in } \\
\text { China }\end{array}$ & $\begin{array}{c}\text { Jiangxi Science \& } \\
\text { Technology Normal University }\end{array}$ \\
\hline $\begin{array}{c}\text { Discussions } \\
\text { on class } \\
\text { Practice in } \\
\text { Lab }\end{array}$ & few & Many times \\
$\begin{array}{c}\text { Practice in } \\
\text { pharmaceutical } \\
\text { factory }\end{array}$ & $\begin{array}{c}\text { ppt+teachers } \\
\text { write on the } \\
\text { blackboard+teacher } \\
\text { teaching }\end{array}$ & Many times \\
Teaching & $\begin{array}{c}\text { ppt+teachers } \\
\text { write on the } \\
\text { blackboard+teacher } \\
\text { teaching }\end{array}$ & New methods \\
Teaching & fimes & \\
reform & few & \\
& &
\end{tabular}

As we know, Pharmacy major and Pharmaceutical engineering major are applied majors and the students of these two majors need much practice. Only doing enough practice in lab and pharmaceutical factory that the students can learning the knowledge well. What's more, when they graduate from school and work in company, they are competent for their own jobs. In a word, practical ability is very important for the students of Pharmacy major and Pharmaceutical engineering major. The more practice of them, the strong of the ability of the students.

Medicinal chemistry is an important course for students of these two majors and medicinal chemistry is also a course needing much practice and much experiment. Therefore, the traditional way for teaching medicinal chemistry is not suit for the current students.

Therefore, teaching reformation of medicinal chemistry course of pharmacy major and pharmaceutical engineering major is argent. Many attempts should be carried out in teaching medicinal chemistry, especially in local normal university.

Here, in this paper, we introduced one new method for medicinal chemistry course for undergraduate in School of Pharmacy, Jiangxi Science \& Technology Normal University. And the advantages and disadvantages for the two methods were discussed.

\section{METHODS}

Method of comparative analysis and Market research and analysis were applied in our project [19-25].

Before we start this project, firstly, we carried out an investigation for teaching methods of medicinal chemistry most of the universities in China, and then the results are the important basis for the teaching reform of medicinal chemistry.

Secondly, according to the results, we design a reasonable and practicable plan for the reform that is the book and the plan for practice. We carry out our practice in class and several pharmaceutical companies in Nan Chang of Jiangxi provinces, which are very near to our school. We can go to the pharmaceutical companies by bus so that we can decrease the spending of this project.

Thirdly, the material for the class such as exam paper and discussion content must be prepared before the class.

We choose two classes from Pharmacy major and pharmaceutical engineering major in School of Pharmacy, Jiangxi Science \& Technology Normal University as subjects. And any one of them (named class one) was choose as the references group using traditional teaching methods. The other group (named class two) was chose as experiment group using the new teaching methods.

We chose the same book, the same teacher and the same teaching time for these two classes. Class one has 31 students and Class two has 15 students. For different groups, we chose different way for this course. We applied new method for class two and traditional method for class one.

Firstly, we change the way of teaching students. In traditional, we teach the course of medicinal chemistry through the traditional method of "ppt+teacher write on the blackboard+teacher teaching" in class one. However, we teach the course of medicinal chemistry not only through the traditional way, but also discussion on class and practice in Lab and pharmaceutical factory in class two.

Secondly, the total teaching time for class one and class two is the same. There' s 51 hours of theory in class one and in class two there is only 36 hours of theory but there is still 15 hours discussion and practice time.

Thirdly, the discussion and exercise in class one and class two is different. In class one, no discussion was carried out and few exercise should be finished in class one. While in class two, several times for discussions and exercise for each class were needed.

Finally, mid-examination and finally examination were carried out in class two, and the scores is one of the important aspects for finally scores.

TABLE II. DifFERENCES BETWEEN Class ONE AND Class Two IN THIS PROJECT.

\begin{tabular}{ccc}
\hline Classes & Class One & Class Two \\
\hline $\begin{array}{c}\text { Students } \\
\text { number }\end{array}$ & 31 & 15 \\
Methods & $\begin{array}{c}\text { Traditional } \\
\text { method }\end{array}$ & New method \\
Teaching & $\begin{array}{c}\text { ppt+teachers } \\
\text { write on the } \\
\text { blackboard+teacher } \\
\text { teaching }\end{array}$ & $\begin{array}{c}\text { Not only the traditional way, } \\
\text { bulso discussion on class and } \\
\text { practice in Lab and } \\
\text { pharmaceutical factory }\end{array}$
\end{tabular}




\begin{tabular}{|c|c|c|}
\hline $\begin{array}{l}\text { Students } \\
\text { participate in } \\
\text { class }\end{array}$ & 1-2 times & More than 6 times \\
\hline $\begin{array}{l}\text { Practices in } \\
\text { lab }\end{array}$ & $\begin{array}{r}\text { Medicinal } \\
\text { chemistry Lab }\end{array}$ & Medicinal chemistry Lab \\
\hline $\begin{array}{l}\text { Practices in } \\
\text { pharmaceutical } \\
\text { componies }\end{array}$ & no & 3-5 times after class \\
\hline Book & $\begin{array}{l}\text { Traditional } \\
\text { Medicinal } \\
\text { Chemistry }\end{array}$ & $\begin{array}{l}\text { Traditional Medicinal } \\
\text { Chemistry }\end{array}$ \\
\hline $\begin{array}{l}\text { Teaching } \\
\text { Time }\end{array}$ & $\begin{array}{l}51 \text { hours of } \\
\text { theory }\end{array}$ & $\begin{array}{l}36 \text { hours of theory }+15 \text { hours } \\
\text { discussion and practice }\end{array}$ \\
\hline Discussions & No discussions & Several times for each class \\
\hline Exercise & Few exercise & Exercise for each class \\
\hline $\begin{array}{l}\text { Mid- } \\
\text { examination }\end{array}$ & $\begin{array}{l}\text { No mid- } \\
\text { examination }\end{array}$ & $\begin{array}{l}\text { Taking mid-examination, } \\
\text { and the scores is one of the } \\
\text { important aspects for finally } \\
\text { scores }\end{array}$ \\
\hline $\begin{array}{c}\text { Finally } \\
\text { examination }\end{array}$ & Test paper & $\begin{array}{l}\text { Not only Test paper, but also } \\
\text { answering the questions by the } \\
\text { teachers, the scores of answering } \\
\text { the questions is including in the } \\
\text { finally scores }\end{array}$ \\
\hline
\end{tabular}

\section{RESULTS}

After two year later, the new method was applied in this class. Some tests were carried out to evaluated whether the new method have some advantages to the traditional way. The results shown that the new method is better and the students in class two learn medicinal chemistry much more better than class one. We can easily find that the mean scores are much higher for the new methods (class one and two). What's more, the students are more satisfied with the new methods while most of the students don't want to attend the traditional medicinal chemistry classes.

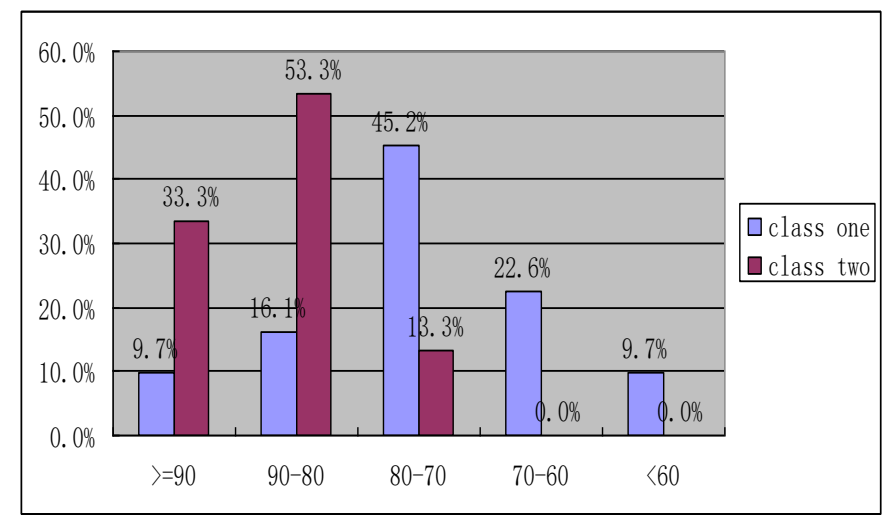

Fig. 1. Statistics of finally scores of the two classes.
From Fig.1. we can know that the scores of the students in class two are much better than that of students in class one. $86.6 \%$ of the students get the scores more than 80 and none of the students get less than 60 .

The students that score less than 60 in class two is $9.7 \%$. This results told us that the students in class two learn medicinal chemistry is much better than class one which using the traditional teaching methods.

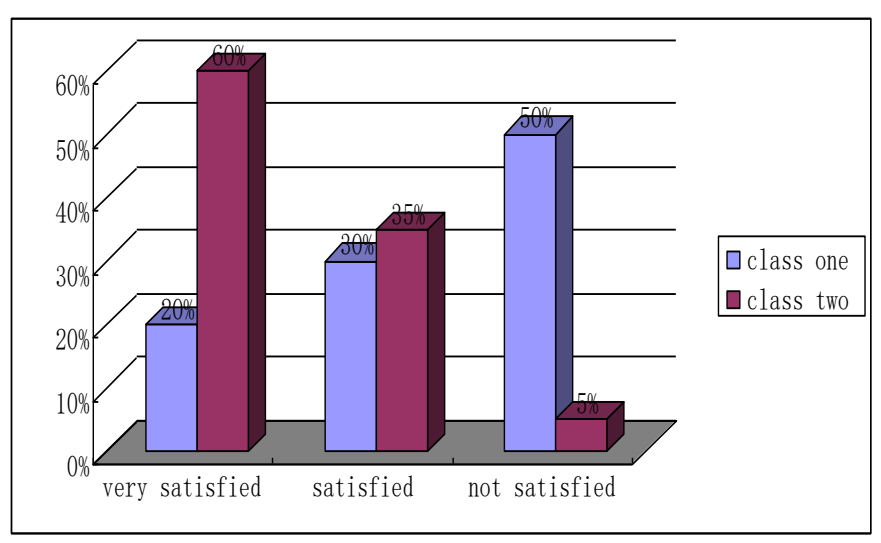

Fig. 2. Statistics of Satisfaction degree of the two classes toward the different teaching methods.

From Fig.2. we can know that the students of class two are much more satisfied with the teaching methods, nearly all of them $(95 \%)$ are satisfied and only one student $(5 \%)$ is not satisfied. While the numbers in class two are different from class one, only $50 \%$ of the students satisfied with the traditional teaching methods of medicinal chemistry. Importantly, there is nearly $50 \%$ of the students not satisfied with the traditional methods.

The skill of the students teaching by the new methods improved a lot and is much better than that teaching by the traditional methods due to the discussion on class and practice in Lab and pharmaceutical factory. The results also suggested that the new method has many advantages.

\section{CONCLUSION}

In this paper, the traditional way for teaching medicinal chemistry and a new method was discussed. The different methods applied in the different classes. The results showed that the new method has many advantages, such as higher exam scores, much more popular to the students and the new method can improve the ability and learning ability in medicinal chemistry course of the undergraduate students.

This teaching method can also be applied in other similarly course such as pharmaceutics and pharmacology course and further study of this teaching method will be carried out in near future. We hope that more and more students will like this teaching method in teaching specialized course

\section{ACKNOWLEDGMENT}

We gratefully acknowledge the generous support provided by the higher education educational reform research project of 
Jiangxi Province (JXJG-13-10-19) and higher education educational reform research project of Jiangxi Science \& Technology Normal University (JGZD-13-10-9\& JGYB-1424-18)

\section{REFERENCES}

[1] Medicinal chemistry. Wikipedia. https://en.wikipedia.org/wiki/Medicinal_chemistry,2015-8-20.

[2] Krogsgaard - Larsen P, Pelliciari R, De Souza N, et al. Medicinal chemistry education: What is needed and where is it going?[J]. Drug development research, 2005, 66(1): 1-8.

[3] Jia-qiang Y. Cultivation of Students' Innovation Ability in the Medicinal Chemistry Teaching [J]. Researches in Medical Education, 2007, 12: 023 .

[4] Webster A A, Riggs R M. A quantitative assessment of a medicinal chemistry problem-based learning sequence[J]. American journal of pharmaceutical education, 2006, 70(4).89

[5] Herrier R N, Jackson T R, Consroe P F. The use of student-centered, problem-based, clinical case discussions to enhance learning in pharmacology and medicinal chemistry[J]. Am J Pharm Educ, 1997, 61(4): 441-446.

[6] Currie B L, Chapman R L, Christoff J J, et al. Patient related case studies in medicinal chemistry[J]. American Journal of Pharmaceutical Education, 1994, 58(4): 446-450.

[7] Roche V F, Zito S W, Aitken M J. Evaluation of computerized medicinal chemistry case study modules as tools to enhance student learning and clinical problem-solving skills[J]. American Journal of Pharmaceutical Education, 1999, 63: 289-295.

[8] Brown S D. A process-oriented guided inquiry approach to teaching medicinal chemistry[J]. American journal of pharmaceutical education, 2010, 74(7)

[9] Rodrigues R P, Andrade S F, Mantoani S P, et al. Using Free Computational Resources To Illustrate the Drug Design Process in an Undergraduate Medicinal Chemistry Course[J]. Journal of Chemical Education, 2015, 92(5): 827-835.

[10] Islam M A, Schweiger T A. Students' Perception of an Integrated Approach of Teaching Entire Sequence of Medicinal Chemistry, Pharmacology, and Pharmacotherapeutics Courses in PharmD Curriculum[J]. Journal of pharmacy practice, 2015, 28(2): 220-226.

[11] Pitman S, Xu Y Z, Taylor P, et al. Spotlight on medicinal chemistry education[J]. Future medicinal chemistry, 2014, 6(8): 865-869.

[12] Flynn A B, Biggs R. The development and implementation of a problem-based learning format in a fourth-year undergraduate synthetic organic and medicinal chemistry laboratory course $[\mathrm{J}]$. Journal of Chemical Education, 2011, 89(1): 52-57.

[13] Kolluru S. An active-learning assignment requiring pharmacy students to write medicinal chemistry examination questions[J]. American journal of pharmaceutical education, 2012, 76(6).

[14] Khan M O F, Deimling M J, Philip A. Medicinal chemistry and the pharmacy curriculum $[\mathrm{J}]$. American journal of pharmaceutical education, 2011, 75(8).

[15] Alsharif N Z, Galt K A, Mehanna A, et al. Instructional model to teach clinically relevant medicinal chemistry[J]. American journal of pharmaceutical education, 2006, 70(4).

[16] Brown S D. A process-oriented guided inquiry approach to teaching medicinal chemistry[J]. American journal of pharmaceutical education, 2010, 74(7).

[17] Conway S E, Johnson J L, Ripley T L. Integration of team-based learning strategies into a cardiovascular module $[\mathrm{J}]$. American journal of pharmaceutical education, 2010, 74(2).

[18] Khan M O F, Deimling M J, Philip A. Medicinal chemistry and the pharmacy curriculum[J]. American journal of pharmaceutical education, 2011, 75(8).

[19] Xinhui P, Xinbing W, Dongmei Q, et al. A Brief Probe into How to Cultivate Students' Creative Ability on Medicinal Chemistry[J]. The Science Education Article Collects, 2015, 2: 028.
[20] ZHAO Q, SHEN Z, LIU W. The Reforming Research of Pharmaceutical Chemistry Experiment in Transformation of Local Colleges and Universities[J]. Guangzhou Chemical Industry, 2015, 6: 071.

[21] WANG Z, HUANG Q. Application of PBL in Experimental Teaching of Medicinal Chemistry[J]. Guangzhou Chemical Industry, 2015, 1: 071.

[22] Islam M A, Schweiger T A. Students' Perception of an Integrated Approach of Teaching Entire Sequence of Medicinal Chemistry, Pharmacology, and Pharmacotherapeutics Courses in PharmD Curriculum[J]. Journal of pharmacy practice, 2015, 28(2): 220-226.

[23] Johnson B J, Graham K J. A Guided Inquiry Activity for Teaching Ligand Field Theory[J]. Journal of Chemical Education, 2015, 92(8): 1369-1372.

[24] Cullen D M. Modeling Instruction: A Learning Progression That Makes High School Chemistry More Coherent to Students[J]. Journal of Chemical Education, 2015, 92(8): 1269-1272.

[25] Singh P. CBL in Medical Education Effective Learning Methodology than PBL[J]. Int J Intg Med Sci, 2015, 2(8): 145-50. 